\title{
ГЛОБАЛЬНЫЙ ДОЛГ: РАЗМЕР, ДИНАМИКА РОСТА, СТРУКТУРА И РИСКИ ДЛЯ МИРОВОЙ ФИНАНСОВОЙ СТАБИЛЬНОСТИ
}

\author{
В.Д. Андрианов*
}

Анализируется растущий дисбаланс между мировым ВВП и глобальным долгом. Рассматриваются размеры и динамика роста мирового ВВП. Исследуется структура глобального долга, в том числе корпоративный, государственный, банковский долг и задолженность домохозяйств. Отмечаются серьезные риски роста глобального долга для стабильности экономики отдельных стран, мировой экономики и финансовой системы.

Ключевые слова: валовой внутренний продукт, глобальный долг, корпоративный долг, государственный долг, банковский долг, задолженность домохозяйств.

JEL-классификация: F33, F34, G15, G21, G23.

DOI: $10.46782 / 1818-4510-2021-1-101-117$

Материал поступил 18.11 .2020 2

Нынешний глобальный финансовоэкономический кризис еще раз подтвердил несостоятельность на современном этапе экономических теорий монетаризма и кейнсианства, которые долгое время считались мейнстримом в западной экономической науке. Кризис продемонстрировал тупик в развитии неолиберальной модели глобальных дерегулированных финансовых рынков. Так, монетаристы считают, что априори рынки конкурентны и сама рыночная система в случае нарушения устойчивости в состоянии автоматически достигать макроэкономического равновесия. Однако на практике это оказывается не так. В частности, мировой финансово-экономический кризис 2008-2009 гг. начался с краха рынка ипотечного кредитования в США, который рухнул из-за агрессивной кредитной политики крупнейших участников рынка, в том числе структур «теневого» банкинга.

В разгар финансового кризиса практически все ведущие промышленно развитые страны вынуждены были перейти на «ручное» управление экономикой, в лучших тра- дициях классического дирижизма. Без активной политики количественного смягчения, существенных государственных вливаний денежных средств в экономику, перевода корпоративного долга в государственный и национализации обанкротившихся финансовых институтов большинство стран были бы обречены на финансовый коллапс и суверенный дефолт. Мировые регуляторы, стараясь запустить экономический рост, напечатали огромное количество денег, но даже такая масштабная эмиссия не привела к ожидаемому эффекту.

Беспрецедентное вмешательство государства в экономические процессы, к которому всегда призывали сторонники кейнсианства, в данной ситуации не способствовало экономическому росту, а лишь усугубило финансовые проблемы как в отдельных странах, так и в глобальной экономике (Андрианов, 2011). Антикризисные программы ведущих промышленно развитых стран, финансируемые в основном из государственных бюджетов, не смогли преодолеть стагнацию, а многие проблемы, особенно в финансовой

* Андрианов Владимир Дмитриевич (andrianov_vd@mail.ru), доктор экономических наук, профессор Московского государственного университета им. М.В. Ломоносова (г. Москва, Россия). 
сфере государственных финансов и в банковской сфере, обострились и стали основными причинами нового глобального финансового-экономического кризиса, который начался в 2020 г. Поэтому можно констатировать, что причины нового суперкризиса мировой экономики - не пандемия коронавируса и падение цен на нефть, а системные финансовые и социально-экономические дисбалансы.

В настоящее время основными угрозами для углубления кризиса мировой экономики и экономики отдельных стран являются усиливающиеся системные дисбалансы в глобальной экономике и мировой финансовой системе, к которым в первую очередь следует отнести дисбалансы между:

- объемом мирового ВВП и размером глобального долга, а также темпами их роста;

- уровнем капитализации мирового фондового рынка и объемом небиржевых производных финансовых инструментов;

- стоимостью активов традиционной банковской системы и масштабами «теневого» банкинга;

- ростом благосостояния богатых граждан и высоким уровнем бедности большей части населения во многих странах мира.

Анализ параметров указанных дисбалансов позволяет говорить о том, что мировая экономика и мировая финансовая система погружаются в самый глубочайший кризис, который по всем параметрам и последствиям будет превосходить великую депрессию прошлого века.

\section{Глобальный долг и динамика роста мирового ВВП}

Глобальный долг становится реальным тормозом для преодоления кризисных явлений и дальнейшего восстановления и роста мировой экономики, препятствует достижению целей и задач повестки дня ООН в области устойчивого развития до 2030 г. ${ }^{1}$ Глобальный долг является основным фактором, влияющим на мировую фи-

${ }^{1}$ Преобразование нашего мира: повестка дня в области устойчивого развития на период до 2030 г., была принята ООН в сентябре 2015 г. Документ содержит 17 целей, направленных на ликвидацию нищеты, сохранение ресурсов планеты, рост благосостояния граждан и др. В свою очередь, эти цели содержиат 169 конкретных задач, которые должны быть достигнуты до 2030 г. нансовую стабильность, и может стать триггерным механизмом углубления нового мирового финансово-экономического кризиса. Жизнь в долг стала характерным явлением для многих стран мира, что, в свою очередь, является последствием реализации концепции построения общества потребления, формирования соответствующей системы ценностей и жизненных установок для большинства западных стран. В современном мире в долг живут не только отдельные граждане, но и крупные корпорации, банки и целые государства, что ведет к росту совокупного мирового долга, темпы роста которого опережают рост реальной экономики.

За период с 2002 по 2019 г. основной макроэкономический индикатор, мировой ВВП, в физическом выражении увеличился с 34,7 до 87,3 трлн долл. США. Рост в абсолютных размерах составил 2,5 раза (рис. 1). За тот же период динамика увеличения размеров мирового долга характеризовалась следующими данными: 2000 г.87 трлн долл. США, 2002 г. - 86, 2007 г. 149, 2012 г. $-205,2017$ г. - 223, 2018 г. 247, 2019 г. - 253 трлн долл. США. Таким образом, рост глобального долга в абсолютных размерах с начала текущего столетия увеличился почти в 3 раза.

Следует отметить, что для анализа стабильности мировой экономики важен не столько показатель абсолютной величины глобального долга, сколько показатель его соотношения с мировым ВВП. За период с 2000 по 2019 г. отношение глобального долга к мировому ВВП возросло почти в полтора раза - с 246 до 322\%.

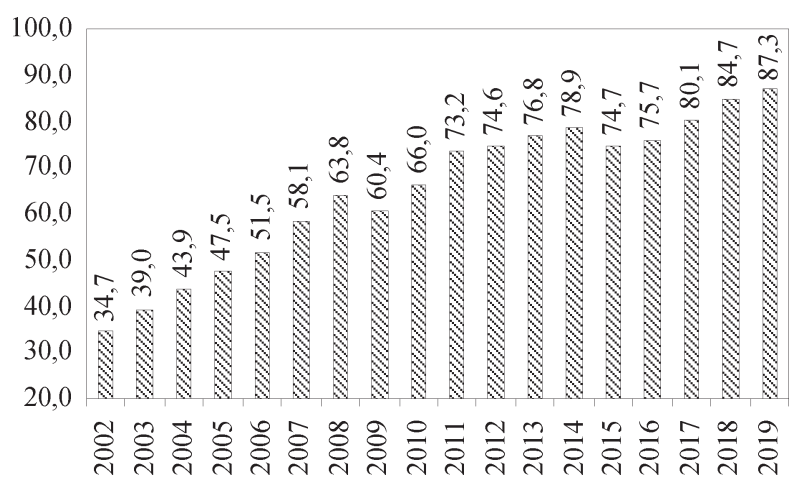

Рис.1. Динамика роста мирового ВВП, млрд долл. США

Источник. International Financial Statistics (IFS). 
Глобальный долг: размер, динамика роста, структура и риски для мировой финансовой стабильности

Одной из причин стремительного роста глобального долга являются сверхнизкие процентные ставки, которые установили денежные власти ведущих промышленно развитых стран для стимулирования экономического роста после мирового кризиса 2008-2009 гг.

Американская ФРС, ЕЦБ и многие другие Центральные банки ведущих стран мира начали играть на понижение ставок с конца 2008 г. в период разгара мирового финансово-экономического кризиса с целью преодолеть стагнацию и поддержать выход национальных экономик на траекторию роста. В результате кредитная активность на потребительском рынке, на рынке недвижимости, долговое финансирование экономики, увеличение кредитования реального сектора экономики и банковской сферы в отдельных странах привели к резкому росту как национального, так и глобального долга.

По данным американского института международных финансов, в конце 2020 г. на фоне сокращения мирового ВВП глобальный долг увеличился до 272 трлн долл. США. При этом почти половина мирового долга приходилась на США (80 трлн долл.) и страны еврозоны (53 трлн долл. $)^{2}$.

Значительный размер мирового долга и затраты на его обслуживание оказывают негативное влияние на динамику роста глобальной экономики, мировое благосостояние и финансовую стабильность в мире, генерируя риски углубления нового финансово-экономического кризиса, начавшегося в 2020 г.

\section{Структура глобального долга}

C начала текущего столетия структура мирового долга принципиально не менялась. В 2000 г. большая часть приходилась на корпоративный долг - 26 трлн долл. США (29,9\%), государственный - 22 трлн долл. $(25,3 \%)$, долги банков - 20 трлн долл. $(20,3 \%)$, задолженность домохозяйств - 19 трлн долл. США (21,8\%) (Dobbs, Lund, Woetzel, Mutafchieva, 2015). При этом постепенно менялась динамика роста состав-

\footnotetext{
2 The Institute of International Finance $>$ Home. URL: https://www.iif.com/
}

ных элементов структуры мирового долга. Если в предкризисный период и во время мирового финансового кризиса 20082009 гг. долг увеличивался в основном за счет заимствований финансового сектора и домашних хозяйств, то после кризиса более быстрыми темпами росла государственная и корпоративная задолженность.

В результате в 2018 г. в структуре мирового долга большая часть приходилась на корпоративный долг - 73,5 трлн долл. США $(29,7 \%)$, государственный - 66,5 трлн долл. $(26,9 \%)$, долги банков - 60,6 трлн долл. $(24,6 \%)$, задолженность домохозяйств - 46,5 трлн долл. США (18,8\%) (рис. 2).

Анализ валютной структуры глобального долга показал, что по-прежнему подавляющая его часть приходится на доллар США, хотя в последние десятилетия его доля постепенно сокращалась с 89,9\% в 2001 г. до 87,0\% в 2013 г. и до 85,0\% в 2018 г.

Уменьшение мирового долга в американских долларах произошло за счет роста задолженности в китайских юанях, российских рублях и индийских рупиях.

Большая часть мирового долга в $72 \%$ (178,3 трлн долл. США) приходилась на промышленно развитые страны, остальные 28\% (69 трлн долл. США) - на развивающиеся государства. Самый высокий темп прироста долга за последние годы был зафиксирован в Китае и в США.

\section{Корпоративный доле}

Более трети глобального долга это корпоративная задолженность, которая с начала текущего столетия имела следующую динамику роста: 2000 г. - 26 трлн долл.



Рис. 2. Динамика мирового долга, трлн долл. США

Источник. Global Debt Monitor. 2018. IIF. URL: https://www.iif.com/Research/Capital-Flows-and-Debt/ Global-Debt-Monitor 
США, 2007 г. - 38, 2014 г. - 56, 2017 г. 65, 2018 г. - 74 трлн долл. США. Таким образом, всего за период с 2000 по 2018 г. мировой корпоративный долг увеличился почти в 3 с лишним раза. При этом его доля в мировом долге сохранилась примерно на том же уровне - 29,7\%. Больше половины корпоративного долга приходилось на промышленно развитые и новые индустриальные страны, в том числе США, Китай, Великобританию, Швецию, Данию, Норвегию, Швейцарию, Канаду, Австралию, Японию, Республику Корея, Сингапур.

\section{Корпоративный долг Китая}

В последние годы наиболее высокими темпами росла корпоративная задолженность в Китае, которая увеличилась с 14 трлн долл. США в 2014 г. до 18 трлн долл. в 2018 г. и до 20 трлн долл. в 2020 г. Корпоративный долг Китая превысил аналогичный показатель США - 16 трлн долл. (совокупный, включая задолженность компаний малого и и среднего бизнеса), всех стран Еврозоны - 12,5 трлн долл., Японии - 4,5 трлн долл. США. Стремительный его рост обусловлен бумом кредитования масштабных инвестиционных проектов в сфере недвижимости и инфраструктурных отраслях КНР.

Для преодоления последствий мирового финансового-экономического кризиса 2008-2009 гг. почти всем провинциям Китая и некоторым крупным городам правительством было официально разрешено привлекать заемное финансирование на внутреннем и международном рынках капитала. При этом часть выпуска новых корпоративных облигаций осуществлялась через Министерство финансов Китая и попадала в листинг фондовых бирж.

Значительная часть денежных средств для реального сектора экономики Китая предоставлялась не официальными банковскими учреждениями, а структурами «теневого» банкинга (shadow banking) ${ }^{3}$. Безудержная раздача кредитов в период 2008-2010 гг. и появление новых альтернативных вариантов заемного финансирования в форме «теневого» банкинга привели к резкому росту кор-

${ }^{3}$ Global Shadow Banking Monitoring Report. 20122019. Financial Stability Board. URL: https://www.fsb.org/ поративной задолженности. Следует отметить, что характерной ее особенностью в Китае является высокий уровень концентрации на крупных государственных предприятиях и в частных компаниях, работающих на рынке недвижимости и в строительстве. При этом значительная часть корпоративной задолженности приходится на внутренние заимствования резидентов, номинированные в юанях. По данным специального исследования Международного валютного фонда (МВФ), на конец 2019 г. основными должниками являлись крупные государственные предприятия, а почти половина корпоративного долга Китая приходилась на 50 крупных компаний базовых отраслей экономики, контрольные пакеты которых принадлежали государству.

К другой группе крупных должников относятся частные компании-девелоперы, их долги постоянно растут, а доходы сокращаются из-за изменения конъюнктуры на рынке недвижимости. Среди китайских фирм, специализирующихся на строительстве и девелоперской деятельности, около $80 \%$ всей корпоративной задолженности приходится на 60 ведущих компаний, у которых в балансе соотношение долговых обязательств и активов превышает 300\%. Такая структура корпоративной задолженности Китая сложилась в результате проведения антикризисной политики через государственные банки - они активно кредитовали прежде всего крупные государственные предприятия и тесно связанные с местными властями компании девелоперов.

В последние годы около 60\% новых корпоративных кредитов китайские компании использовали для погашения старых долгов. В частности, в 2015 и 2016 гг. стоимость новых крупных выпусков китайских корпоративных облигаций фактически превысила общую сумму непогашенных корпоративных облигаций. В такой ситуации для генерирования аналогичной суммы финансовых потоков требуется в четыре раза больше привлечения новых кредитов, чем это было десять лет назад.

В условиях замедления экономического роста, обострения проблемы избыточных мощностей все большее число китайских компаний, в том числе и крупнейших в стране, испытывают трудности в обслужи- 
Глобальный долг: размер, динамика роста, структура и риски для мировой финансовой стабильности

вании накопленных ими долговых обязательств, вплоть до невозможности вернуть деньги кредиторам. Признаком нарастания напряженности на этом рынке стал первый в китайской практике дефолт по корпоративным облигациям. Дефолт был объявлен 14 марта 2014 г. шанхайской компанией «Chaori», специализирующейся на производстве солнечных батарей. В августе 2014 г. о неспособности обслуживать кредиты и осуществлять платежи по своим облигациям объявила еще одна китайская компания - «Huatong2», базировавшаяся в провинции Шаньси и занимавшаяся строительством дорог и мостов.

Следует отметить, что это были первые случаи, когда органы исполнительной власти Китая допустили корпоративные дефолты. Ранее эмитенты корпоративных облигаций, испытывающие трудности с обслуживанием долгов, как правило, в последний момент получали финансовую поддержку от административных структур или государственных банков.

Постепенно этот процесс стал приобретать лавинообразный характер, и в 2019 г. общий объем дефолтов по кредитам в корпоративном секторе достиг 20 млрд долл. США. Чтобы замедлить его, государство старается разными способами приучить участников рынка, в том числе крупные госкомпании, соблюдать жесткую финансовую дисциплину.

Следует отметить, что реальную величину корпоративной задолженности Китая сложно определить, поскольку часто на этом рынке не понятно, где заканчиваются долги предприятий и начинаются долги государства.

\section{Корпоративный доле США}

По размеру корпоративной задолженности в 2020 г. США занимали второе место в мире после Китая. Объем американской корпоративной задолженности крупных компаний за период с 2008 по 2019 г. возрос на 52\% и превысил 10 трлн долл. США, что составило 47\% ВВП страны. По данным аналитиков из «Bank of America», на конец 2020 г. корпоративная задолженность США достигла 10,5 трлн долл. Это относится к долгу компаний, которые вхо- дят в биржевой листинг и котируются на американских фондовых рынках.

Кроме корпоративного долга крупных американских компаний, в последние годы отмечен рост задолженности малых, средних и семейных предприятий, не входящих в биржевой листинг и, соответственно, не котирующихся на фондовых рынках и крупнейших биржах США. Общий объем долга таких компаний на начало 2020 г. оценивается авторитетным американским журналом «Forbes» примерно в 5,5 трлн долл. США.

Таким образом, по нашим оценкам, совокупная корпоративная задолженность крупных корпораций США и предприятий малого и среднего бизнеса в конце 2020 г. достигла 16 трлн долл. США, что значительно превысило американский ипотечный пузырь, вызвавший глобальный финансовый кризис в 2008 г. Из всего объема американского корпоративного долга 99\% было номинировано в долларах США и около 38\% принадлежало резидентам.

По мнению экспертов, одной из основных причин продолжающегося десятилетнего бума корпоративного долга стала растущая у зарубежных инвесторов популярность биржевых инвестиционных фондов (ЕTF exchange-traded fund), акции которых торгуются на бирже. Биржевой фонд является относительно новым видом ценных долговых бумаг, выполняющих роль сертификата на портфель акций, облигаций и др.

Структура ETF, как правило, повторяет структуру выбранного базового фондового индекса (Dow Jones; NYSE; S\&P 500; SPY; SPDR и др.). C ценными бумагами ETF можно производить такие же операции, которые доступны для обыкновенных акций и облигаций в биржевой торговле.

Популяризации биржевых фондов способствовали маркет-мейкеры, которыми выступали обычно крупные американские и зарубежные банки, сотрудничающие с управляющими компаниями, выпускающие паи биржевых фондов и ежедневно рекламирующие их ликвидность на рынке. К таким банкам прежде всего относятся: Goldman, Sachs \& Co, Citigroup Global Markets Inc., Merrill Lynch, Pierce, Fenner \& Smith Incorporated, Morgan Stanley \& Co. LLC, Bank of Nova Scotia, New York Agency, 
Credit Suisse Securities (USA) LLC, BNP Paribas Securities Corp, Deutsche Bank Securities Inc., HSBC Securities (USA) Inc., Barclays Capital Inc., Daiwa Capital Markets America Inc. и др. ${ }^{4}$

Как видно, в этот список входят не только американские банки, но и банки из Великобритании, Франции, Германии, Швейцарии, Японии, Канады. По мнению экспертов, именно эти финансовые структуры являются основными акционерами ФРС, они же реализуют американскую денежно-кредитную политику, являются так называемыми первичными дилерами ФРС и играют определяющую роль на рынке корпоративных ценных бумаг.

Популярность ЕTF в течение последних 10 лет привела к тому, что все виды биржевых фондов торгуются на рынке более активно, чем составляющие их бумаги. В результате в последние годы отмечалось масштабное вливание капиталов в американские фонды облигаций и биржевые фонды, в том числе от местных индивидуальных инвесторов и со стороны иностранных покупателей, что стало существенной поддержкой ликвидности американского корпоративного долгового рынка. Всего на долю иностранных инвесторов в 2020 г. приходилось примерно 27\% корпоративного долга США.

Из общего долга компаний, которые официально котируются на американских фондовых биржах, 7,2 трлн долл. США задолженности приходилось на компании с высоким кредитным рейтингом инвестиционного уровня в диапазоне от ААА до ВВВ.

Очевидно, что для кредиторов высокие инвестиционные рейтинги американских долговых бумаг - важный фактор сохранения надежности инвестиций, поскольку вероятно, что по окончании эпидемии коронавируса, когда компании начнут вновь получать доход, их платежеспособность восстановится и проблем с погашением задолженности не возникнет.

Однако, по оценкам кредитно-рейтингового агентства «Standard \& Poor's», половина корпоративного долга США инвестиционного уровня в размере 3,6 трлн долл. приходилась на долг компаний, акции ко-

${ }^{4}$ URL: https://www.rbc.ru/money/29/08/2017/ 59a59e169a79470a4463823f торых имели кредитный рейтинг уровня BBB.

И хотя корпоративные кредиты американских компаний, как правило, были структурированы безопаснее ипотечных бумаг периода начала нулевых годов текущего столетия, тем не менее у этих корпоративных акций и облигаций отмечался низкий рейтинг надежности. Ценные бумаги по критерию надежности котировались в «пограничном диапазоне» с очень низким инвестиционным рейтингом, который всего на один пункт был выше «мусорного» уровня.

Кроме того, общий объем «мусорных» (бросовых) акций, облигаций (англ. junk bonds, non-investment-grade bond, speculative-grade bond, high-yield bond), с кредитным рейтингом инвестиционного уровня $\mathrm{BA} / \mathrm{BB}$ и еще ниже либо вообще без рейтинга, в конце 2020 г. в корпоративном долге США оценивался примерно в 1,5 трлн долл. США.

Следует отметить, что глобальные инвесторы охотно покупают американские бумаги с высокой доходностью и «мусорным» рейтингом из-за сверхнизких доходностей более качественных долговых инструментов $^{5}$. В частности, согласно исследованию «Deutsche Bank», «мусорные» облигации США за десятилетний период с 9 августа 2007 г. по 9 августа 2017 г. стали вторым по доходности финансовым активом после биржевых фондов на индекс S\&P 500. За этот период американские ценные бумаги «мусорного» инвестиционного рейтинга принесли инвесторам доход на уровне 95\%. Хотя долларовые «мусорные» облигации имели более низкую доходность, чем их европейские аналоги.

Период дешевых денег годами поддерживал на плаву обремененные долгами «компании-зомби», которые потерпели бы крах, если бы ставки заимствований были на приемлемых рыночных уровнях. Такая ситуация на рынке высокодоходных «мусорных» корпоративных ценных бумаг в период нынешнего финансового кризиса может спровоцировать лавинообразный рост дефолтов по этим долговым инструментам.

Для того чтобы понять степень риска, сопряженную с инвестициями в «мусорные»

5 URL: https://www.rbc.ru/money/29/08/2017/ 59a59e169a79470a4463823f 
Глобальный долг: размер, динамика роста, структура и риски для мировой финансовой стабильности

бонды, инвесторы обычно изучают статистику дефолтов по таким ценным бумагам. В частности, на мировом рынке, по оценкам «Moody's», свои обязательства перед держателями долга в 2019 г. не смогли выполнить 4,5\% эмитентов, имевших неинвестиционные рейтинги. Примерно такой же уровень дефолтов у корпоративных эмитентов со спекулятивными рейтингами констатирует агентство «Standard \& Poor's» (S\&P), отмечая, что в 2016 г. на долговом рынке США дефолта не смогли избежать $5,1 \%$ компаний с «мусорными» рейтингами своих акций.

По подсчетам ведущего американского инвестбанка «Goldman Sachs», дефолты на рынке высокодоходных корпоративных облигаций США в 2019 г. достигли самого высокого уровня со времен прошлого финансового кризиса. При этом даже крупнейшие американские корпорации ограничены в финансовых средствах и с трудом обслуживают свои долги. По информации аналитиков МВФ, проблемы с оплатой текущих долгов в 2019 г. возникли у ведущих американских транснациональных компаний - «Ford Motor», «AT\&T», «CVS Health» и др. В 2020 г. в связи с началом нового финансового кризиса число таких компаний значительно увеличилось. В целом низкое качество корпоративного долга США в условиях нового финансового кризиса 2020 г. многократно усилило финансовые проблемы в американской экономике.

В настоящее время международные инвесторы обеспокоены тем, что экономический спад или продолжительный цикл понижения рейтингов компаний на фондовых рынках ниже отметки ВВВ может затопить рынок «мусорных» облигаций. В первую очередь, подвержены наибольшему риску дефолтов «мусорные облигации», затем займы, предоставляемые компаниям с высоким уровнем задолженности, затем облигации, утратившие свой рейтинг, потом фирмы, рейтинг которых был понижен до минимального инвестиционного уровня.

Высокий уровень корпоративного долга в США, его низкое качество на фоне пандемии и развития нового мирового финансово-экономического кризиса стали одной из причин периодического обрушения фондовых рынков США в течение 2020 г. В особо тяжелом финансовом состоянии оказались энергетические компании США, в том числе в сфере добычи сланцевой нефти и газа. Ситуация усугубилась падением мировых цен на энергоносители в начале 2020 г. По оценкам экспертов, если цены на нефть сохранятся на прежнем низком уровне, около $30 \%$ сланцевых производителей США не смогут обслуживать свои долги.

Стоимость ценных бумаг американских энергетических компаний, которые пострадали от падения цен на энергоносители в конце 2020 г., оценивалась в 936 млрд долл. США, из них акции на сумму 110 млрд долл. торговались в так называемом проблемном сегменте фондового рынка (distressed territory) с доходностью до 10\%. До конца 2020 г. американским энергетическим компаниям нужно погасить 27 млрд долл. США корпоративной задолженности. При этом у многих компаний в разы выросли риски корпоративных дефолтов. В частности, акции американской компании «SM Energy» в результате фондовых кризисов упали на 50\%, «Callon Petroleum»на 40\%, «Oasis Petroleum» - на 40\%, «Occidental Petroleum» - на 15\% ${ }^{6}$.

Сложная ситуация на рынке корпоративной задолженности вынудила денежные власти США привлечь к ее решению Федеральную резервную систему (ФРС). Отметим одно удивительное совпадение - ВОЗ объявила о пандемии коронавируса 13 марта 2020 г., а уже 22 марта 2020 г. представители ФРС сняли ограничения на политику количественного смягчения (QE Quantitative Easing).

Впервые в своей истории ФРС в 2020 г. разработала и стала реализовывать серию программ экстренного кредитования частных компаний и выкупа корпоративных долгов компаний, находящихся на грани банкротства. В рамках очередной программы количественного смягчения ФРС сформировала два специальных механизма поддержки крупных компаний. Программы запущены уже 23 марта 2020 г., и на эти цели были выделены 300 млрд долл. США.

Первая программа Primary Market Corporate Credit Facility (PMCCF) создана

${ }^{6}$ По данным агентства «Market Watch», октябрь 2020 г. URL: https://www.marketwatch.com/ 
для первичного рынка с целью расширения кредитования корпоративного сектора путем выпуска новых облигаций, привлечения новых кредитов и займов и предназначена для американских компаний, имеющих рейтинг инвестиционного уровня, которые смогут получить временное финансирование на четыре года. Причем в первые шесть месяцев компании могут быть освобождены от выплаты основной суммы долга и процентов по нему7.

Поскольку ФРС не имеет возможности напрямую давать займы и кредиты частным компаниям, были использованы ее полномочия для создания специальных механизмов, которые, в свою очередь, обеспечили расширение кредитования и получение новых займов. В частности, расширены валютные своп-линии с центральными банками различных стран. Это прежде всего пять крупнейших Центральных банков - Европейский центральный банк (ЕЦБ), Банк Англии, Национальный банк Швейцарии, Банк Канады, Банк Японии, с которыми у ФРС заключено соглашение о неограниченном обмене в рамках валютного свопа.

ФРС также рекомендовала банкам проявлять гибкость в отношении клиентов, испытывающих финансовые проблемы изза коронавируса, и использовать при этом свои буферы ликвидности, смягчения требований к обязательному резервированию и достаточности капитала. Кроме того, ФРС продолжила проведение операций репо, в рамках которых банки получают средства под залог ценных бумаг. Ставка по таким операциям была снижена до нуля.

Чтобы защитить себя от потерь по кредитам в рамках нового механизма поддержки корпоративного сектора, ФРС планирует использовать 10 млрд долл. США из собственного фонда валютной стабилизации (Exchange Stabilization Fund).

Вторая программа Secondary Market Corporate Credit Facility (SMCCF) предназначалась для обеспечения ликвидности вторичного рынка корпоративных бондов. Она предусматривала начиная с мая 2020 г. по-

${ }^{7}$ Report to Congress Pursuant to Section 13(3) of the Federal Reserve Act: Primary Market Corporate Credit Facility. May 29, 2020. Board of Governors of the Federal Reserve. купку ценных бумаг биржевых фондов (ETF), имеющих листинг в США, и с июня 2020 г. выкуп корпоративных бондов американских корпораций, имеющих инвестиционный рейтинг ${ }^{8}$.

В апреле ФРС принял еще одну специальную программу по смягчению проблемы задолженности компаний малого и среднего бизнеса и обеспечению их новыми кредитами - Main Street Business Lending Program (MSBLP). На ее реализацию было выделено 350 млрд долл. США. В частности, регулятор предоставил ликвидность банкам, выдающим кредиты малому и среднему бизнесу. Залогом такого финансирования стали займы в их номинальном размере. Кроме того, в рамках программы кредитования малого и среднего бизнеса ФРС выкупит займы таких компаний на сумму до 600 млрд долл., в том числе 75 млрд долл. на эти цели выделит Министерство финансов США. У банков-кредиторов останется 5\% таких займов, остальные 95\% долгов они смогут продать регулятору. Участниками этой программы смогут стать малые и средние компании, образованные до 13 марта 2020 г., с хорошими докризисными финансовыми показателями, имеющие до 1015 тыс. занятых, годовой оборот до 2,5 млрд долл. США и доход не более 5 млрд долл. ${ }^{9}$

В перспективе ФРС планирует продолжить использовать весь спектр инструментов для поддержания корпоративного сектора и тем самым содействовать достижению целей максимального смягчения проблемы корпоративного долга.

\section{Корпоративный долг России}

Корпоративная задолженность российских компаний начала формироваться по мере их роста и выхода на мировые рынки капитала в середине 90-х годов прошлого столетия по двум каналам - через банковский и небанковский секторы.

В небанковском секторе корпоративная задолженность стала образовываться в

${ }^{8}$ Report to Congress Pursuant to Section 13(3) of the Federal Reserve Act: Secondary Market Corporate Credit Facility. March 30, 2020. Board of Governors of the Federal Reserve.

${ }^{9}$ Report to Congress Pursuant to Section 13(3) of the Federal Reserve Act: Main Street Business Lending Program. April 9, 2020. Board of Governors of the Federal Reserve. 
Глобальный долг: размер, динамика роста, структура и риски для мировой финансовой стабильности

результате первичного публичного размещения ценных бумаг компаний (IPO initial public offering) на мировых фондовых биржах.

Первой российской компанией, организовавшей и осуществившей первичное публичное размещение своих ценных бумаг за рубежом, стал «ВымпелКом», акции которого были включены в листинг НьюЙоркской фондовой биржи (NYSE) 20 ноября 1996 г. (Андрианов, 1999). Акции «ВымпелКома» в виде американских депозитарных расписок (ADR) третьего, самого высшего, уровня были размещены на бирже под символом «VIP». Это позволило компании привлечь более 60 млн долл. США на развитие сети.

Как правило, в долговые обязательства корпоративного сектора включают кредиты, в том числе торговые, долговые обязательства перед компаниями, осуществлявшими прямые инвестиции, текущие счета и депозиты, в том числе до востребования, долговые ценные бумаги, задолженность по финансовому лизингу и др.

До мирового финансово-экономического кризиса 2008-2009 гг. крупные российские промышленные компании и банки часто кредитовались за рубежом напрямую, получали синдицированные кредиты, организовывали выпуск еврооблигаций и использовали другие долговые финансовые инструменты. Сложившаяся ситуация объяснялась, прежде всего, тем, что возможности долгосрочного кредитования реального сектора экономики в России были ограничены неразвитостью рынка капитала и высокими кредитными ставками. Не было финансовых площадок мирового уровня для первичного размещения акций публичных компаний.

В то время руководители российских кредитных организаций отмечали значительный отток отечественных заемщиков к иностранным банковским и финансовым организациям. Особенно это было заметно по динамике заимствований крупных российских компаний и банков, в том числе с государственным участием.

По данным Банка России, с 1999 по 2005 г. объем внешних заимствований российских компаний и банков увеличился с
1,2 до 98 млрд долл. США, т. е. в 80 с лишним раз (см. табл.). В тот период в условиях укрепления курса рубля и высокого уровня ставки рефинансирования заимствования за рубежом в иностранной валюте были значительно выгоднее. Поэтому государственные компании и компании с государственным участием активно использовали заимствования, и прежде всего в виде синдицированных кредитов у ведущих западных банков.

В 2005 г. среди российских компаний с государственным участием крупнейшими заемщиками были ОАО «Газпром», ОАО «Роснефть», «Совкомфлот», РАО «РЖД», «Транснефть», «АЛРОСА», которые привлекли кредитов на сумму свыше 28 млрд долл. США.

Внешние займы крупнейших российских банков с государственным участием Сбербанка, Внешторгбанка, Внешэкономбанка и Россельхозбанка - в 2005 г. составили 6,45 млрд долл. США, или $36 \%$ всех внешних заимствований российской банковской системы.

Кроме того, активно привлекали внешние займы российские коммерческие банки - ОАО «Росбанк», «Юникредитбанк», «Банк Москвы», «Русский стандарт», «Московский кредитный банк» и др.

Следует отметить, что значительная часть внешней корпоративной задолженности России приходилась на оффшорные юрисдикции. Это связано с так называемым кредитным инвестированием, когда

Таблица

Динамика внешних заимствований российских компаний и банков

\begin{tabular}{|c|c|}
\hline Год & млрд долл. США \\
\hline 1999 & 1,2 \\
\hline 2000 & 3,2 \\
\hline 2001 & 6,4 \\
\hline 2002 & 17,9 \\
\hline 2003 & 33,4 \\
\hline 2004 & 38,8 \\
\hline 2005 & 98,0 \\
\hline
\end{tabular}

Источник. Данные Банка России. 
прямые инвестиции в Россию замещались дешевыми кредитами, что в известной мере страховало инвестиционные риски благодаря возможности использовать международный арбитраж.

В дальнейшем данная тенденция сохранилась. Перед мировым финансово-экономическим кризисом 2008-2009 гг. совокупный внешний долг российских компаний имел следующую динамику роста: 2006 г. - 163 млрд долл. США (в т. ч. банковский - 50 млрд), 2007 г. - 314 млрд (в т. ч. банковский - 130 млрд), 2008 г. - 436 млрд долл. США (в т. ч. банковский - 171 млрд).

Большая часть внешнего долга государственного и частного корпоративного секторов России была накоплена именно в этот период. Доминирующим сегментом в секторе российских еврооблигаций являлись еврооблигации государственных компаний, составлявшие $58 \%$ объема рынка корпоративных еврооблигаций.

Многие займы российским государственным корпорациям выдавались с условием, что кредитор вправе потребовать досрочный обратный выкуп облигаций, если бумаги на рынке потеряют инвестиционный рейтинг. Так и случилось во время острой фазы мирового финансово-экономического кризиса в конце 2008 г., когда у крупных российских компаний возникли проблемы с ликвидностью и возможностью обслуживать долговые обязательства перед зарубежными финансовыми организациями.

В целях недопущения дефолта крупнейших системообразующих российских компаний и рефинансирования их корпоративного внешнего долга, возникшего до 25 сентября 2008 г., в соответствии с Федеральным законом от 17 октября 2008 г. № 173-Ф3 «О дополнительных мерах по поддержке финансовой системы Российской Федерации» было поручено Внешэкономбанку предоставить необходимые финансовые ресурсы для погашения внешних долговых обязательств российских компаний. Рефинансирование осуществлялось за счет депозитов Банка России. За период с октября 2008 г. по декабрь 2009 г. Внешэкономбанк выдал кредиты десяти крупнейшим российским компаниям и одному бан- ку на общую сумму в 11,6 млрд долл. США, что позволило предотвратить их дефолт и переход стратегических активов в собственность иностранных кредиторов.

Среди государственных корпораций наибольшую задолженность, по их собственным данным, в 2015 г. имели компания ОАО «Роснефть» в размере 63 млрд долл. США и компания ОАО «Газпром» - 55 млрд долл., что в сумме составляло почти четверть всего корпоративного долга России.

В посткризисный период продолжался рост общей корпоративной задолженности России, которая в 2015 г. достигла своего максимума в 630,1 млрд долл. США. В целом, пик погашения корпоративной задолженности прошел достаточно гладко, все долговые обязательства были выполнены в соответствии с графиком погашения основного долга и процентов по нему без задействования дополнительных источников предоставления валютной ликвидности со стороны государства.

В последующие годы корпоративный долг отечественных компаний, предприятий, организаций стал постепенно снижаться и в 2018 г. составлял 344,6 млрд долл. США, в 2019 г. - 314,2 млрд долл. Соответственно, сокращались ежегодные выплаты по долгам.

В 2020 г. отмечался незначительный рост российской корпоративной задолженности на 2,6\% до 322,6 млрд долл. США. Тем не менее ее размер по-прежнему остается самым значительным в структуре общего внешнего долга России, в 2020 г. он составлял 481,5 млрд долл. США. Доля корпоративной задолженности - 67\%, из которых примерно половина принадлежит резидентам и чуть больше $50 \%$ номинировано в рублях (на конец 2020 г. $-22,6$ трлн руб., или примерно $20 \%$ от ВВП).

Корпоративная задолженность России была больше планируемых доходов бюджета страны на 2021 г. в размере 18,8 трлн руб. и больше расходов федерального бюджета в размере 21, 5 трлн руб. Проведенный анализ показал, что почти половина всей задолженности приходилась на компании энергетического сектора. При этом $38 \%$ долга в размере 8,7 трлн руб. имели всего 2 крупнейшие российские энергетические компании ПАО «Газпром» и ПАО «Рос- 
Глобальный долг: размер, динамика роста, структура и риски для мировой финансовой стабильности

нефть». Единственная энергетическая компания без внешней задолженности в 2020 г. - компания Сургутнефтегаз.

Следует отметить, что крупные российские энергетические корпорации, несмотря на наличие значительной внешней задолженности и международные санкции, продолжают привлекать иностранную валюту за счет выгодных предложений иностранных банков, которые часто на внутреннем рынке имеют отрицательные ставки по кредиту, а также успешно размещать свои долговые ценные бумаги на международных рынках капитала в условиях мирового финансового кризиса, сложной рыночной конъюнктуры и откровенно враждебного антироссийского информационного фона.

Основным финансовым инструментом, позволяющим организовывать выпуск и обращение российских ценных корпоративных бумаг на зарубежных фондовых рынках, являются ADR (американские депозитарные расписки) и GDR (глобальные депозитарные расписки). Самыми популярными биржами для них стали западные площадки (LSE, FSE) и американские ведущие фондовые биржи (NYSE, NASDAQ).

Кроме того, российские корпоративные бумаги активно торгуются на крупнейших азиатских биржах Сингапура и Гонконга.

По мере сокращения общего размера внешнего корпоративного долга России, прохождения пика выплат по нему с 2019 г. отмечается устойчивая тенденция к сокращению как годовых, так и квартальных выплат основной части долга и процентов по нему. В настоящее время размер корпоративного долга России, в отличие от американской и китайской корпоративной задолженности, не столь значителен и не представляет серьезной угрозы финансовой стабильности как самих компаний-заемщиков, так и всей кредитно-банковской системы страны.

\section{Государственный долг}

Чуть больше четверти глобального долга приходится на государственную задолженность, которая с начала текущего столетия имела следующую динамику роста: 2000 г. - 22 трлн долл. США, 2007 г. - 33,
2014 г. - 58, 2017 г. - 60, 2018 г. - 67 трлн долл. США. В 2018 г. государственная задолженность всех стран мира составляла почти $80 \%$ мирового ВВП ${ }^{10}$. Согласно оценкам МВФ, по итогам 2020 г. совокупный государственный долг всех стран мира впервые превысил величину глобального ВВП и составил 101,5\% мирового ВВ ${ }^{11}$.

В физическом выражении самый большой госдолг имели США, который к концу 2019 г. достиг 23 трлн долл., а в 2020 г. превысил 27 трлн долл., что составляло 40\% госдолга всех стран мира. Начиная с 2017 г. госдолг США превышает стоимость ВВП и в 2019 г. составлял 107\% ВВП, а в конце 2020 г. превысил 131\%, побив рекордный показатель 1946 г. - 126\% ВВП. На каждого американца приходилось больше 50 тыс. долл. государственной задолженности. Только на обслуживание растущего госдолга в США тратилось до $25 \%$ от ВВП.

Отсутствие увеличения доходности по долгосрочным государственным облигациям США свидетельствует о том, что ФРС может потерять контроль над процентными ставками на фоне нивелирования кривой доходности этих ценных бумаг.

Развитие указанных тенденций привело к тому, что ведущие международные рейтинговые агентства вынуждены были понизить кредитный рейтинг США до «негативного», тем самым увеличив риски финансовой стабильности.

По прогнозам Бюджетного управления Конгресса США, соотношение госдолга и ВВП может вырасти к 2023 г. до 117\% и к 2049 г. до 144\% от ВВП страны.

Государственный долг Японии в абсолютном выражении в 2018 г превышал 10 трлн долл. США. При этом страна занимала первое место в мире по отношению государственного долга к ВВП, который составлял 251\%. В течение длительного периода времени Япония не может преодолеть стагнацию экономики. На этом фоне растут внутренние заимствования для покрытия расходов по социальным обязательствам. В результате старения населения страны и роста числа пенсионеров значи-

\footnotetext{
${ }^{10}$ Quarterly External Debt Statistics (QEDS). 2019. IMF.

${ }_{11}$ The Institute of International Finance > Home. URL: https://www.iif.com/
} 
тельно увеличились расходы на социальные нужды. В 2020 г. госдолг Японии вырос до $266,2 \%$ ВВП.

В последние годы наиболее высокими темпами растет государственный долг Китая, который увеличился с 1,3 трлн долл. США в 2008 г. до 6,6 трлн долл. в 2018 г. Отношение госдолга к ВВП за тот же период возросло с 35,3 до 49,3\%, и по этому показателю в 2018 г. Китай занимал 95 место в мире. В 2020 г. госдолг Китая увеличился до 61,7\% ВВП.

Из европейских стран самый большой размер государственного долга имела Италия - 2,7 трлн долл. США. Самый высокий показатель соотношения госдолга и ВВП в 2018 г. в Европе был у Греции - 178\%, Италии - 132\%, Португалии - 127\%. Бельгии 106\%, Франции - 99\%, Испании - 98\%.

Следует отметить, что в соответствии с Пактом стабильности и роста (англ. Stability and Growth Pact, SGP) Европейского союза государственный долг стран-членов не должен превышать 60\% от ВВП. В настоящее время большинство стран еврозоны не в состоянии соблюдать это условие.

В 2020 г. отношение госдолга к ВВП в Греции выросло до 205,5\%, в Италии - до $170 \%$, в Испании и Португалии - до 140\%.

Среди развивающихся стран мира наиболее высокий указанный показатель (в 2018-2020 гг.) был в Судане - 259\%, Венесуэле - 240, Ливане - 174, Эритреи - 156, Белизе - 135, Бахрейне - 128, Бутане 122, Замбии - 119, на Мальдивах - 118, Ямайке - 116, в Республике Конго - 104\%12.

На этом фоне состояние государственных финансов России можно назвать достаточно сбалансированным. В 2018 г. госдолг России составлял 518 млрд долл. США, что соответствовало 19,3\% ВВП. По данному показателю страна занимала 175 место в мире, а государственный долг не на много превышал объем золотовалютных резервов страны (468 млрд долл. США). Россия относится к немногим странам мира, где госдолг сокращается, в 2020 г. этот показатель составлял 18,9\% ВВП.

Кроме внутренних долговых инструментов, Россия, несмотря на санкции, ак-

${ }^{12}$ Global Debt Monitor. June 2018. IIF; Global Debt Monitor. November 2020 IIF; The Institute of International Finance >Home. URL: https://www.iif.com/ тивно использует внешние заимствования, главным образом в форме евробондов.

Основными покупателями при размещении в 2018 г. евробондов «Россия-29» и «Россия-47» стали институциональные инвесторы из Великобритании и США. Долг России в иностранной валюте в 2018 г. составлял 380 млрд долл. США.

В 2019 г. Россия привлекла на международных рынках 5,5 млрд долл. США и 750 млн евро. По данным Минфина, спрос на долговые обязательства России в 3 раза превышал предложение.

Бюджет на 2020 г. предполагает возможность привлечения внешних заимствований в эквиваленте до 3 млрд долл. США. Однако Минфин, скорее всего, больше не сможет занимать в долларах США, так как в таких трансакциях должны участвовать американские банки.

В августе 2019 г. США ввели дополнительные санкции против России, запретив участие американских банков в первичных размещениях облигаций, номинированных не в рублях, выпущенных российским правительством или Банком России.

Любой долларовый платеж проходит через американский банк-корреспондент, даже если он не покупает эти бумаги. После введения санкций американским банкам было запрещено любое участие в первичных размещениях российских валютных государственных бумаг. Поэтому денежные власти России вряд ли смогут в обозримом будущем выпускать новые еврооблигации, номинированные в долларах США. В таком случае внешние заимствования могут быть заменены на бумаги, номинированные в других иностранных валютах (евро, юанях и др.), или на внутренние, возможно, в новой форме специальных инвестиционных облигаций, увязанные с инфраструктурными и национальными проектами.

Для многих стран мира, где размер государственной задолженности не превышает 60\% ВВП, сам по себе госдолг не является проблемой. Как правило, правительству нет необходимости полностью погашать долги, они могут быть пролонгированы, реструктурированы или рефинансированы. 
Глобальный долг: размер, динамика роста, структура и риски для мировой финансовой стабильности

Тем не менее, значительные размеры государственного долга становятся для многих стран мира препятствием долгосрочного экономического роста. Согласно оценкам экспертов, негативный эффект для устойчивого экономического роста появляется при достижении государственного долга на уровне $90 \%$ ВВП. Когда уровень государственного долга превышает эту границу, частная инвестиционная активность начинает снижаться в силу потери доверия к государственным гарантиям и эффективности функционирования государственных финансов. Для стран с высокой долей долга в ВВП в результате увеличения государственной задолженности и расходов на ее обслуживание существуют повышенные риски кризиса суверенных долгов.

По мнению экспертов, самыми уязвимыми странами в силу их зависимости от валютных долгов, номинированных, как правило, в долларах США, являются: Колумбия (более $75 \%$ заимствований в долл. США) Мексика (62\%), Бразилия (50\%) Аргентина, Ливан, Чили, Венгрия, Турция, Польша, Египет, Саудовская Аравия, Нигерия, ЮАР.

Погасить созданные колоссальные государственные долги в оговоренные сроки многие страны не смогут. Для погашения или уменьшения задолженности государству сложно генерировать соответствующие новые финансовые потоки без существенного ущерба для финансовой стабильности.

Государственный долг становится серьезной проблемой, когда растет быстрее ВВП. В настоящее время именно такой тренд укрепился в глобальной экономике, и в ближайшие годы он сохранится.

После мирового финансового кризиса политику количественного смягчения с операциями на открытом рынке кроме ФРС США активно проводили Европейский ЦБ, Банк Англии, Банк Японии и др. В результате в мировой финансовой системе сложилась парадоксальная ситуация - Центральные банки ведущих промышленных стран стали крупнейшими институциональными инвесторами в мире.

У крупнейших мировых ЦБ на балансах скопились огромные объемы государственных ценных бумаг, причем среди них преобладают облигации с отрицательной доходностью. В 2019 г. мировой рынок государственных ценных бумаг с отрицательной доходностью оценивался примерно в 13,7 трлн долл. США.

\section{Суверенные дефолты}

В начале мирового кризиса 2020 г. парад суверенных дефолтов начался с Ливана. В частности, премьер-министр Ливанской Республики Хасан Диаб 7 марта 2020 г. заявил, что правительство приняло решение отказаться от выполнения своих обязательств по погашению части внешнего долга страны в размере 1,2 млрд долл. США, номинированного в еврооблигациях. Общая государственная задолженность Ливана в 2020 г. достигла 90 млрд долл. США, что составляло почти $170 \%$ ВВП страны. При этом $60 \%$ долга приходилось на иностранных инвесторов. В своем обращении к нации премьер-министр заявил, что государство не может тратить сегодня валютные ресурсы на погашение задолженности, которые нужны на закупку продовольствия и лекарств для населения. Вину за суверенный дефолт Хасан Диаб возложил на предыдущее правительство, которое проводило ошибочную экономическую политику. В результате вместо реформирования экономики накапливались долги, что породило масштабную коррупцию. Существующая банковская система позволяла получать сверхприбыль незначительному количеству банкиров, в то время как $40 \%$ граждан Ливана оказались за чертой бедности.

Следует отметить, что до гражданской войны 1975-1990 гг. Ливан был процветающим государством, финансовой и банковской столицей арабского мира, его называли Ближневосточной Швейцарией.

Правительство Ливанской Республики вступило в переговоры с иностранными кредиторами и надеется на помощь международных экспертов в реструктуризации внешней задолженности. Кроме того, оно разрабатывает план экономических реформ, направленных на возрождение промышленности, развитие информационных технологий, сферы туризма и услуг.

Таким образом, 7 марта 2020 г. можно считать началом нового глобального финан- 
сово-экономического кризиса. В ближайшее время следует ожидать суверенного дефолта других стран, и прежде всего стран с высокой долей государственного долга в ВВП.

Вслед за Ливаном о суверенном дефолте в середине 2020 г. объявила Аргентина. Это стал 9-й финансовый дефолт за всю историю страны. К сентябрю 2020 г. правительству удалось договориться с кредиторами об реструктуризации долговых обязательств. О своей финансовой несостоятельности и неплатежеспособности 16 ноября 2020 г. объявила Замбия. По нашему мнению, в течение 2021 г. суверенные дефолты могут объявить Ангола, Камерун, Кения, Пакистан.

В апреле 2020 г. министры финансов стран G20 в связи с началом мирового финансово-экономического кризиса договорились о временном моратории на платежи по внешним государственным долгам со стороны 73 беднейших стран мира. Если этот мораторий не будет продлен в 2021 г., то число суверенных дефолтов в мировой экономике возрастет.

\section{Банковский доле}

Четверть глобального долга приходится на задолженность финансовых организаций, которая с начала текущего столетия имела следующую динамику роста: 2000 г. - 20 трлн долл. США, 2007 г. - 37, 2014 г. - 45, 2017 г. 56, 2018 г. - 61 трлн долл. США.

Следует отметить, что мировой банковский долг был выше уровня капитализации мировой банковской системы.

Наибольший прирост банковского долга показал Китай, где он увеличился со 110 млрд долл. США в 2010 г. до 785 млрд долл. в 2018 г. Данный тренд указывает на растущую уязвимость финансового сектора КНР, и прежде всего за счет снижения качества кредитного портфеля (Неер, 2014).

По оценкам экспертов швейцарского Банка международных расчетов, наиболее высокие риски финансовой стабильности от роста банковской задолженности имели Канада, Китай и Гонконг.

Особо выделяется Канада, где банковская задолженность в 2018 г. достигла 1,8 трлн долл. США, что составляло $105 \%$ от
ВВП страны (1,7 трлн долл.). На одного жителя страны приходилось 22,8 тыс. долл. США долговых обязательств, без учета задолженности по ипотеке. Столь высокие показатели закредитованности населения создают серьезные риски для банковской системы Канады.

В Гонконге в 2019 г. финансовые проблемы, в том числе в сфере банковского кредитования, усугубились ростом политической напряженности.

На этом фоне внешняя задолженность банковской системы России выглядит не столь критичной. До мирового финансовоэкономического кризиса банковская задолженность имела следующую динамику роста: 2005 г. - 32 млрд долл. США, 2006 г. - 50, 2007 г. - 130, 2008 г. - 171 млрд долл. США. Большая часть внешних займов приходилась на банки с государственным участием, в том числе «Сбербанк», «Внешторгбанк», «Внешэкономбанк» и «Россельхозбанк».

В конце 2014 г. общая внешняя задолженность российского банковского сектора достигла своего пика в 207,7 млрд долл. США, в том числе задолженность Банка России составляла 15,6 млрд долл.

После введения экономических санкций и возникших проблем с привлечением новых внешних займов банковская задолженность России к 2017 г. уменьшилась почти в два раза до 113,7 млрд долл. США. В последующие годы эта тенденция сохранилась: в 2018 г. банковский долг сократился до 103,4 млрд долл. США, в 2019 г. до 85,3 млрд долл. Тенденция к снижению внешней задолженности банков объясняется прежде всего тем, что Россия прошла пик выплат по старым банковским долгам, а новые заимствования ограничены экономическими санкциями ведущих промышленно развитых стран.

\section{Задолженность домохозяйств}

Пятая часть мирового совокупного долга приходилась на задолженность домохозяйств, которая с начала текущего столетия имела следующую динамику роста: 2000 г. - 19 трлн долл. США, 2007 г. - 33, 2014 г. - 40, 2017 г. - 41, 2018 г. -47 трлн долл. США. 
Глобальный долг: размер, динамика роста, структура и риски для мировой финансовой стабильности

Самый большой долг сохраняли домохозяйства США. Общий американский долг домохозяйств рос шесть лет подряд и в начале 2019 г. достиг своего исторического максимума в 13,9 трлн долл. США, что составляло почти треть мирового долга домохозяйств. Рост долга населения связывают прежде всего с тем, что домохозяйства используют преимущества низкой процентной ставки для получения кредитов.

Большую часть долга составляют ипотечные кредиты - 9,4 трлн долл. США (68\%), при этом задолженность по ипотеке превысила показатель 2008 г. (9,3 трлн долл.), когда разразился ипотечный кризис в США, переросший в глобальный финансово-экономический кризис.

Рекордных показателей достигла задолженность по автокредитам - 1,32 трлн долл. США $(9,5 \%)$, на образовательные кредиты приходилось 1,5 трлн долл. (10,8\%), задолженность по кредитным картам составляла 880 млрд долл. США $(6,3 \%)^{13}$.

Следует подчеркнуть, что именно массовый выпуск ипотечных кредитов с высокой степенью риска и массовая секьюритизация долгов явились основной причиной ипотечного кризиса в США, который стал триггерным механизмом запуска глобального финансово-экономического кризиса - его можно рассматривать как кризис потери контроля и дерегулирования финансовой системы.

Снижение учетной ставки ФРС почти до нулевой отметки способствовало тому, что Америку буквально залило дешевой ликвидностью, которая в виде ипотечных кредитов выдавалась людям без дохода, без работы, под залог будущих активов, без страховки и др.

Эта ситуация на рынке ипотечного кредитования вполне может повториться в ближайшие годы, учитывая высокий уровень задолженности, сохраняющиеся низкие кредитные ставки и достаточно высокую долю просроченной задолженности.

По уровню долговой нагрузки населения среди стран G7 первое место занимает Канада. По данным статистической службы, общая кредитная задолженность семей в Ка-

${ }^{13}$ Отчет Федерального резервного банка США. 2019. URL: https://www.federalreserve.gov/ наде в 2018 г. составила 1,6 трлн долл. США (2,2 трлн канадских долларов) - ее размер вплотную приблизился к размеру ВВП страны (1,7 трлн долл. США). Из общей суммы задолженности домохозяйств 63\% приходилось на ипотечные кредиты и $37 \%$ - на автокредиты и другие потребительские кредиты.

Отношение долга домохозяйств Канады к их чистому доходу с 1990 по 2018 г. выросло почти в два раза и составляло $179 \%$. Иными словами, на каждый полученный канадской семьей доллар дохода в среднем приходилось 1,8 канадских доллара долга по кредитам. Очевидно, что такая ситуация может спровоцировать снижение уровня потребления и привести к замедлению темпов роста экономики. Проведенные исследования отмечают сокращение спроса на недвижимость, автомобили и туристические поездки.

Долг домохозяйств Китая в конце 2018 г. вырос до 8,5 трлн долл. США и составил $60,4 \%$ ВВП. При этом впервые отношение долга домашних хозяйств к их доходу достигло 99,9\%, фактически долг сравнялся с реальными доходами населения ${ }^{14}$. Подавляющая часть задолженности приходилась на ипотечные и потребительские кредиты, остаток задолженности по кредитным картам в 2018 г. достиг почти 1 трлн долл. США.

Эксперты Народного банка Китая полагают, что быстрый рост задолженности домохозяйств, особенно в форме ипотечных и потребительских кредитов, генерирует дополнительные риски финансовой устойчивости кредитно-банковской системы страны.

Для поддержания экономического роста Правительство Китая принимает меры по стимулированию потребления, однако в условиях значительного увеличения объема ипотечного и потребительского кредитования это может привести к кризису задолженности домохозяйств.

Долги домохозяйств в России за период с 2013 по 2019 г. выросли почти в два раза - с 8,5 до 15,9 трлн руб. (258 млрд долл. США $)^{15}$. И хотя в абсолютных разме-

${ }^{14}$ Отчет о финансовой стабильности Народного банка Китая. 2018. URL: http://www.pbc.gov.cn/

${ }_{15}$ Данные Центрального банка Российской Федерации. URL: https://cbr.ru/ 
рах эти долги не сравнимы с американскими и китайскими, тем не менее в 2019 г., как и в США, они достигли своего исторического максимума.

Согласно данным Банка России, почти вся задолженность домохозяйств приходится на долги банкам. При этом кредитная активность населения проявляется на фоне сокращения реально располагаемых ими доходов, которые только за период с 2014 по 2018 г. снизились на 11\%.

Вместе с долгами растет официальный уровень просроченной задолженности, который в 2018 г. составлял 6,1\%. Однако реальный уровень таких долгов, по оценкам экспертов, может быть в два раза больше примерно 10-12\%.

С целью стимулировать экономический рост после мирового финансово-экономического кризиса 2008-2009 гг. мировые регуляторы активно использовали механизм долгового финансирования, но это не привело к ожидаемому эффекту, поскольку модель массового потребления зашла в тупик.

Таким образом, чтобы поддерживать даже небольшие темпы роста мировой экономики и отдельных стран мира, денежным властям приходится увеличивать ликвидность, использовать эмиссионный механизм и, соответственно, занимать на разных уровнях все больше и больше. Этот процесс можно охарактеризовать как классическую финансовую пирамиду на государственном, корпоративном, банковском и на уровне отдельных домохозяйств. Как показывает мировой опыт, любая финансовая пирамида рано или поздно заканчивается крахом.

При условии повышения процентных ставок стоимость новых заимствований увеличится, что потенциально при пролонгации или реструктуризации текущих долгов может привести к неконтролируемому росту количества суверенных дефолтов и банкротствам в реальном секторе экономики.

Таким образом, текущий экономический рост, поддерживаемый ускоряющимся наращиванием мировой задолженности, может пострадать в долгосрочной перспективе, когда глобальная экономика начнет испытывать давление со стороны заемщиков, не выдержавших бремя долговой нагрузки. И если данный процесс примет лавинообразный характер, ущерб от него может значительно превысить определенные дивиденды, полученные мировой экономикой от десятилетия кредитной гонки. В этой связи не исключено, что нынешний мировой финансово-экономический кризис может стать кризисом долга, так как именно на этом рынке раздут огромный финансовый пузырь. Поэтому, по нашему мнению, в разгар экономического кризиса самое большое обесценение может произойти именно с долговыми бумагами, что окажет негативное влияние на общую финансовую стабильность в мире.

Анализ текущей глобальной финансовой ситуации и продолжающийся рост мирового долга могут иметь разрушительные экономические последствия, станут своеобразной финансовой «дислокацией».

Если в условиях нового мирового финансово-экономического кризиса крупные экономики не выдержат долговой нагрузки, международные финансовые институты будут не в состоянии оказать им адекватную поддержку. Тогда разрушительная сила возможной финансовой нестабильности многократно увеличится, что вызовет масштабные финансовые шоки в мировой экономике и в экономике отдельных стран мира.

\section{СПИСОК ЛИТЕРАТУРЫ (REFERENCES)}

Андрианов В.Д. 1999. Россия: экономический и инвестиционный потенциал. Москва: Экономика. 662 с. [Andrianov V.D. 1999. Russia: Economic and investment potential. Moscow: Ekonomika. 662 p. (In Russ.)]

Андрианов В.Д. 2011. Новая архитектура глобальной финансовой и экономической системы: возможные контуры. Проблемы теории и практики управления. № 9. C. 8-15. [Andrianov V.D. 2011. The new architecture of global financial and economic system: Eventual contours. Problemy teorii i praktiki upravleniya. No 9. PP. 8-15. (In Russ.)]

Heep S. 2014. China in Global Finance: Domestic Financial Repression and International Financial Power. Springer International Publishing.

Dobbs R., Lund S., Woetzel J., Mutafchieva V. 2015. Debt and (not much) deleveraging. Report McKinsey Global Institute. 124 p. 


\title{
GLOBAL DEBT: AMOUNT, GROWTH PATTERNS, FRAMEWORK AND RISKS FOR GLOBAL FINANCIAL STABILITY
}

\author{
Vladimir Andrianov ${ }^{1}$ \\ Author affiliation: ${ }^{1}$ Lomonosov Moscow State University (Moscow, Russia). \\ Corresponding author: Vladimir Andrianov (andrianov_vd@mail.ru).
}

ABSTRACT. The article analyses the growing imbalance between world GDP and the global debt. The amount and growth patterns of world GDP are considered. The framework of global debt, including corporate, public, bank and household debts, is studied. Risks of global debt growth for sustainability of domestic economies, global economy and financial system are stated.

KEYWORDS: GDP, global debt, corporate debt, public debt, bank debt, household debt.

JEL-code: F33, F34, G15, G21, G23.

DOI: $10.46782 / 1818-4510-2021-1-101-117$

Received 18.11 .2020 